\title{
Vernacular Feminism: Gendered Media Cultures and Historical Perspectives on Postdiscourse
}

Television \& New Media 2020, Vol. 21 (6) 67I-675

(C) The Author(s) 2020 (c) (i) (8)

Article reuse guidelines: sagepub.com/journals-permissions DOI: I0.1 I77/I527476420922976 journals.sagepub.com/home/tvn

(SSAGE

\section{Yvonne Tasker'}

\begin{abstract}
Although media studies as a discipline has long been involved in various theoretical elaborations of the "post," it has been concerned far less often with the past that is purportedly posted. In this piece, the concept of postfeminism provides a useful case to highlight how thoughtful engagement with the past has immense value for contemporary media scholarship. I suggest that postfeminist scholarship has typically tackled history only obliquely-via generational tropes-and that a more direct engagement with media history allows an understanding that reaches past the "now" with which postdiscourse tends to concern itself. Patterns of continuity and change have been brought into view through the access to historical media formats facilitated by digital archives. I propose a concept of vernacular feminism as a tool for analyzing historical postfeminism, pointing to the broader relevance for postdiscourses that involve an evocation of the past in the present.
\end{abstract}

\section{Keywords}

postfeminism, vernacular feminism, media history, generations, archives, postdiscourse

If one looks at contemporary culture, one might say that the proliferation of "posts" in our culture speaks to our deep concern with history at the beginning of the twenty-first century: from postmodern and postcolonial novels to more popular forms of culture. (Kennedy 2017, 20-21)

\footnotetext{
'University of Leeds, UK

Corresponding Author:

Yvonne Tasker, School of Media and Communication, Faculty of Arts, Humanities and Cultures, University of Leeds, I.23 Clothworkers North, Leeds LS2 9JT, UK.

Email:Y.Tasker@leeds.ac.uk
} 
Media studies has long been involved in various theoretical elaborations of the "post" but has concerned itself far less often with the past that is purportedly posted. Whether that which is left behind in what Tanya Ann Kennedy terms postdiscourses, are the theoretical modes developed for a particular context or the nuances and cultural texture of particular historical periods, I want to argue here that looking to the past matters. There is, I will suggest, real value for contemporary feminist media scholarship in the so-called historical turn. Such a turn has sometimes been cast negatively as involving a turning away from the present: immersion in past objects as an alternative to the complexities of the now, as if historical media studies were an exercise in nostalgia at worst, of only academic interest at best. Thoughtful engagement with the past is invaluable for understanding the present, even as media forms rapidly evolve. Neither is such historical work at odds with the theoretical explorations of identity, difference and affect that have proven so productive in recent media and cultural studies thinking. Indeed, I would suggest that when the intellectual work of posting engages with questions of periodization and history, it yields important insights for our field of study.

Postfeminism provides my principle example here. Within media studies, it has proven an extraordinarily rich and productive framework for the analysis of gender cultures that are replete with contradictory discourses of freedom and modernity on one hand, discipline and nostalgia on the other. For some thirty years, feminist media scholars have grappled with the meaning and significance of postfeminism. I define it quite broadly, as a set of discourses through which industrialized societies with complex mass media systems simultaneously acknowledge the importance of gender equality while perpetuating profoundly hierarchical gender cultures. Postfeminist discourse frames feminism simultaneously in terms of past achievements (important battles, such as the right to vote or equal pay legislation, won) and as having gone "too far," demanding now seemingly unnecessary social change. Although it has been in use for decades, the vast majority of scholarship exploring the concept of postfeminism is concerned with contemporary culture: postfeminism is understood as being of the "now," even as the now unfolds in new and even unpredictable ways. Postfeminist media scholarship is in many ways profoundly limited by its fixation on the now, precisely because it occludes the history which is so vital to the analysis of gender and media, and also the interaction of gender with other positionalities.

Postfeminism is often characterized as a double discourse; both naïve and selfaware, postfeminist discourse looks backward and forward simultaneously, equally bound up with nostalgia and modernity. Within most accounts, the origin point of postfeminism is located somewhere in the late 1980 s or early 1990 s. I first encountered what I would come to call postfeminism in the late $1980 \mathrm{~s}$, researching some of the ways in which popular culture had seized on and incorporated feminist tropes. One striking example was a print advertisement for the now-defunct travel brand "Club 18-30" which marketed holidays to young people organized around promises of an implicitly sexualized freedom; emblazoned over images of happy, youthful white men and women in beach attire appeared the slogan "A Woman's Right to Choose," a playful commercial co-option of a slogan associated with feminist campaigns for reproductive rights. In retrospect, this advertisement seems very much of its time, for 
example, in its intertextual engagement with political rhetoric and its appearance in print media at a time which predated current digital modes of marketing and communication. An appeal to the rhetoric of choice, and the cheeky evocation of feminism it involves, was not unprecedented however.

As the prefix "post" implies, ideas about history are already very much at stake in the concept of postfeminism. Indeed, Tanya Ann Kennedy, quoted at the outset of this piece, nicely pinpoints the way in which history is acutely at stake when mobilizing a variety of "post-discourses," postfeminism and postracialism being her particular concern. In this context, we can note that generational rhetoric is a recurrent theme by which historical change is obliquely figured in both media texts and postfeminist scholarship. Generational differences have provided a ready way of expressing contradictions as well as alluding to gendered ideas of historical time; indeed, the place where history is perhaps most explicitly in evidence in the scholarship which analyzes postfeminist culture is in its preoccupation with generations, and in particular the figure of the young woman (see McRobbie 2013). Yet, for media studies, a focus on the new and the young obscures as much it reveals: an emphasis on the new has tended to downplay historical patterns from which we might learn, while an emphasis on the young has tended to set aside the complications posed by the co-existence of multiple generations.

Raymond Williams developed his concept of a structure of feeling in precisely this context, aiming to account for a "felt sense of the quality of life at a particular place and time" (Williams 1961, 47). He argues that any particular historical and geographical location, accessible to us largely via media and cultural artifacts, retains the traces of the past through the experiences and aspirations of different generations. Elsewhere he writes of his concern with "meanings and values as they are actively lived and felt . . . thought as felt and feeling as thought" (Williams 1977, 132). Postfeminist media scholarship too is concerned with "thought as felt and feeling as thought," emphasizing abstract ideas of choice and freedom in tandem with narrowly delineated models of the life well-lived. It pinpoints the manner in which commodity culture demonstrates an ongoing capacity to convert ideas of liberation into a financial transaction. For feminist media studies, understanding the commodification of equality discourse historically (rather than in generational terms) has the potential to illuminate in new ways.

By contrast, the discursive association between feminist politics and a parent generation whose radicalism is erased by postfeminist cultural accommodations, risks a profound sense of generational disjuncture. Neither intergenerational disappointment nor intergenerational forgetting is new within media culture: in her 1956 series of articles published in the Evening Standard, "London's Bachelor Girls," filmmaker and journalist Jill Craigie wrote with mingled admiration and exasperation of "the girl in her twenties" who "enjoys her status and rights without the least curiosity as to how they were won. She behaves like a feminist but has turned feminism into a dirty word" (cited in Rollyson 2005, 150); designated with the derogatory term "flappers," young women of the 1920s from diverse social backgrounds were also rhetorically framed as repudiating a previous generation of feminist activists while reaping its rewards. Such rhetoric sets figures of carefree youth against forgotten activism, celebrating liberation while mourning a sense of duty and responsibility in a double move itself characteristic of postfeminism. 
It is mass media and popular culture that postfeminist scholarship understands as the key spaces in which ideas about what it is to be a gendered subject are elaborated. Forms such as women's magazines, advertising, reality television, musical performance, and celebrity culture produce and reproduce gender cultures. Understanding these media forms through an historically informed postfeminism which explores the layering of past and present - what I am terming here vernacular feminism - allows us to trace the repeated and mundane ways in which media forms work through the territory of feminism; what does it mean for women to have citizen status? How does it feel in tension with the insistent construction of women as lesser, as not-men? How does the 1920s figure of the flapper reframe discourses of and anxieties about female independence? How did such discourses play out for women of color, or for queer cultures?

Media analysis can productively interrogate everyday cultural responses to feminist equality goals of the kind with which postfeminism is so intimately concerned. It is this sense of feminism as felt, as part of the texture of media artifacts that can usefully be teased out within an historical frame. Indeed, such an approach is grounded in media history, dependent on an understanding of media texts as complex sites for the articulation of ideas within a particular time and place. This is not about reading feminism's absence or presence in everyday media forms and cultural practices deemed progressive or otherwise. Rather, it involves tracing the ways in which the media cultures of different historical moments have responded to or redefined feminist equality goals. The vernacular points to the importance of everyday forms of language, whether verbal or visual. A form of slang or common speech, idioms provide insight to ways of thinking and feeling about society. Vernacular feminism thus describes the multiple and complex ways in which cultural and media forms incorporate seemingly new or modern ideas about gender. Thus, while we know that postfeminist media culture works to incorporate selected elements of feminist challenge into its idioms, the vernacular is a process that works to make alien elements familiar, known or reassuring. Think of the persistent association between women and machinery - cars, planes, trains- in journalism, cinema and fiction of the 1920s and early 1930s (the celebrity image of American aviator Amelia Earhart, for instance). This imagery evokes themes of modernity, movement, and independence, which are resonant for feminism while being bound up with aspirational ideas of travel and wealth available to relatively few women.

I began with an evocation of late-1980s advertising (“A Woman's Right to Choose”), a postfeminist mode that seems to be related to, but also rather different from, the tropes of thirty years later (that is the "now" of writing). I've also referred to examples from the 1950s and the 1920s, noting commonalities of a postfeminist media discourse that speaks to women from a particular place and time. In postulating postfeminism as a continuum, I do not want to suggest that everything collapses into the same. Rather I am seeking to underline how important it is to locate the "now" in relation to the past, to think about media discourses historically. Thus, postfeminist media modes can be seen to emerge from a long history of discursive negotiations with goals of gender equality extending back at least to the 1910s and 1920s (in the case of the United Kingdom and the United States), when women's right to vote shifts from a ludicrous proposition to a new status quo. Campaigns for suffrage and the aftermath of their 
success were intensely mediated, figured in popular media culture in ways that ranged from hostility or humor to acceptance. For contemporary feminist media studies to effectively interrogate "thought as felt and feeling as thought" depends on the tracing of themes and trends as well as discontinuities and departures through an engagement with media artifacts. Tracing such responses to women's changing citizen status allows partial access to everyday, taken-for-granted assumptions for multiple generations and positionalities at different moments.

The point has pertinence for postdiscourses more broadly since, I want to suggest, the value of the post for media scholarship is precisely in its evocation of the past in the present, an evocation which allows us to trace discursive developments. I've argued here that media analysis enables us to talk about the evolution of meaning in ways that speak to the everyday (vernacular) purchase and power of discourse, and that doing so requires an engagement with media histories. It is noteworthy in this context that the historical patterns I point to here, both continuities and developments, have been brought into view through the access to historical media formats facilitated in recent years by innovations in archiving and the digital humanities.

\section{Declaration of Conflicting Interests}

The author declared no potential conflicts of interest with respect to the research, authorship, and/or publication of this article.

\section{Funding}

The author received no financial support for the research, authorship, and/or publication of this article.

\section{References}

Kennedy, Tanya Ann. 2017. Historicizing Post-Discourses: Postfeminism and Postracialism in United States Culture. New York: State University of New York Press.

McRobbie, Angela. 2013. The Aftermath of Feminism: Gender, Culture and Social Change. London: Sage.

Rollyson, Carl. 2005. To Be A Woman: The Life of Jill Craigie. New York: ASJA Press.

Williams, Raymond. 1961. The Long Revolution. London: Hogarth Press.

Williams, Raymond. 1977. Marxism and Literature. Oxford: Oxford University Press.

\section{Author Biography}

Yvonne Tasker is professor of media and communication at the University of Leeds. Her areas of expertise include feminist media studies; gender and sexualities in cinema and culture; women filmmakers and media history; and postfeminist culture. She is the author of Soldiers' Stories: Military Women in Cinema and Television since WWII(2011), Gendering the Recession: Media Culture in an Age of Austerity (ed. with Diane Negra, 2014), and The Hollywood Action and Adventure Film (2015). 